\title{
Proses Koneksi Matematis Siswa Kelas VIII Masalah Segiempat
}

\author{
Riska Indah Wardina ${ }^{1}$, I Nengah Parta ${ }^{1}$, Hendro Permadi ${ }^{1}$ \\ Pendidikan Matematika-Universitas Negeri Malang
}

\begin{tabular}{l}
\hline INFO ARTIKEL \\
\hline Riwayat Artikel: \\
Diterima: 08-05-2019 \\
Disetujui: 12-11-2019 \\
\hline
\end{tabular}

\section{Kata kunci:}

mathematical connection; mathematical connection process; rectangular,

koneksi matematis;

proses koneksi matematis; segiempat

\section{ABSTRAK}

\begin{abstract}
The purpose of this study is to describe the students' mathematical connection process in solving quadrilateral problems. The approach used is a descriptive explorative qualitative approach. This research was carried out in class VIII of SMP 5 Malang. The instrument used in this study was a test and interview protocol Students selected as research subjects are students who indicate a mathematical connection process that includes guessing, interpreting, calculating, interpreting, and generalizing. The results of the study indicate that connections made by students can be categorized as developing connections. This is because students are able to reason logically in developing new connections through the same problems with the context of the problem given
\end{abstract}

\begin{abstract}
Abstrak: Tujuan penelitian ini adalah mendeskripsikan proses koneksi matematis siswa dalam menyelesaikan masalah segiempat. Pendekatan yang digunakan adalah pendekatan kualitatif berjenis deskriptif-eksploratif. Penelitian ini dilaksanakan di kelas VIII SMPN 5 Malang. Instrumen yang digunakan dalam penelitian ini berupa tes dan protokol wawancara. Siswa yang dipilih menjadi subjek penelitian adalah siswa yang mengindikasi proses koneksi matematis yang meliputi menduga, menafsirkan, menghitung, menafsirkan, dan menngeneralisasikan. Hasil penelitian menunjukkan bahwa koneksi yang dibuat oleh siswa dapat dikategorikan sebagai koneksi berkembang. Hal ini dikarenakan siswa mampu bernalar secara logis dalam mengembangkan koneksi baru melalui masalah yang sama dengan konteks masalah yang diberikan.
\end{abstract}

\section{Alamat Korespondensi:}

Riska Indah Wardina

Pendidikan Matematika

Universitas Negeri Malang

Jalan Semarang 5 Malang

E-mail: wardina898@gmail.com

Belajar matematika melibatkan proses pengembangan skema, yang secara alami mengharuskan siswa untuk menghubungkan ide-ide terkait (Downton \& Sullivan, 2017). Pengembangan skema tersebut terjadi ketika seseorang mengalami proses kognitif. Sedangkan aktivitas menghubungkan ide-ide matematis yang saling terkait disebut sebagai proses koneksi matematis. Eli dkk, 2013 menyatakan bahwa koneksi matematis digambarkan sebagai bagian dari skema atau kelompok skema yang terhubung dalam jaringan mental. Meskipun koneksi matematis telah dijelaskan dalam berbagai cara, koneksi matematis secara umum disebut sebagai penghubung atau jembatan antara ide-ide matematis. Dengan demikian, apabila siswa belajar matematika diharapkan mampu memahami konsep-konsep matematika melalui aktivitas koneksi matematis. Koneksi antara konsep matematika yang berbeda, dapat membantu siswa untuk mengembangkan pemahaman mereka tentang bagaimana menghubungkan konsep-konsep ini dengan pengetahuan sebelumnya (Zengin, 2019).

Koneksi matematis yang dibuat oleh siswa memiliki karakteristik yang berbeda-beda, dan dikelompokkan dalam dua jenis koneksi. Seperti pernyataan García-García \& Dolores-Flores (2018), koneksi matematis dibedakan menjadi dua jenis koneksi, yaitu intra-mathematical connections: koneksi antar konsep matematika dan extra-mathematical connections: koneksi antar disiplin ilmu lain atau dengan kehidupan sehari-hari. Pernyataan tersebut selaras dengan pendapat (Kuneni, Mardiyana, \& Pramudya, 2017) yang menyatakan bahwa secara umum terdapat dua jenis koneksi matematis, yaitu koneksi dalam matematika itu sendiri dan koneksi antara matematika untuk disiplin lain dan matematika dalam kehidupan sehari-hari. Koneksi dalam matematika itu sendiri, yakni pemahaman konsep, memanfaatkan beberapa konsep dalam matematika, hubungan antara pengetahuan konseptual dan prosedural, serta membuat generalisasi dari beberapa pernyataan dalam matematika. Dengan demikian, dapat dinyatakan bahwa jenis koneksi secara garis besar terbagi menjadi dua, yaitu koneksi antara matematika dengan matematika, dan koneksi antara matematika dengan disiplin ilmu lain (yang didalamnya juga termasuk antar kehidupan sehari-hari). 
Hal ini didukung oleh pernyataan (Ozgen, 2016), bahwa klasifikasi koneksi matematika, dapat dinyatakan bahwa koneksi antara matematika dan dunia nyata, koneksi dengan berbagai disiplin ilmu dan koneksi dengan matematika itu sendiri biasanya sering dibahas dalam banyak studi penelitian. Proses koneksi matematis akan diciptakan oleh siswa pada saat mereka mengerjakan masalah-masalah matematika. Hal ini sesuai dengan pernyataan (Lockwood, 2011) bahwa koneksi matematis terjadi selama proses pemecahan masalah. Dasar utama yang diperlukan dalam pemecahan masalah matematika adalah koneksi matematis. Tanpa adanya koneksi matematis, masalah matematika tersebut tidak akan terselesaikan. Sebagaimana pendapat Arjudin dkk (2016) bahwa koneksi matematis digunakan sebagai alat dalam memecahkan masalah matematika. Artinya, siswa yang dapat membuat koneksi matematis dengan tepat berarti siswa tersebut dapat menyelesaikan masalah secara tepat pula. Tahapan/langkah pemecahan masalah yang dituliskan oleh siswa merupakan cerminan dari proses koneksi yang telah dibuatnya. Proses koneksi matematis dapat diketahui melalui langkah siswa dalam membuat koneksi matematika (Islami dkk, 2018). Artinya, proses koneksi matematis siswa dapat dideskripsikan dengan berpedoman pada representasi secara matematis maupun mental yang telah diungkapkan siswa dalam menyelesaikan masalah matematika yang di dalamnya memuat langkah-langkah koneksi. Dengan demikian, kita dapat mengetahui urutan secara sistematis koneksi antar ide-ide matematika yang telah dibuat.

Langkah-langkah koneksi yang dibuat oleh siswa membentuk suatu tingkatan koneksi matematis. (Eli dkk., 2013) mengemukakan bahwa ada lima tingkatan koneksi matematis, yaitu (1) categorical adalah koneksi yang melibatkan sifat sederhana sebagai dasar untuk menentukan kelompok atau kategori; (2) characteristic/property adalah koneksi yang melibatkan pendefinisian karakteristik atau menggambarkan sifat konsep dalam konsep lain; (3) curricular adalah koneksi yang berkaitan dengan urutan ide atau konsep yang dampaknya berkaitan dengan kurikulum, termasuk urutan mengajarkan konsep-konsep atau topik; (4) procedural adalah koneksi yang melibatkan ide-ide yang berkaitan berdasarkan prosedur matematika atau algoritma yang dimungkinkan melalui konstruksi contoh; (5) derivational adalah koneksi yang melibatkan pengetahuan tentang suatu konsep untuk membangun atau menjelaskan konsep lain. Menurut (García-García \& Dolores-Flores, 2018) tingkatan koneksi yang dibuat oleh siswa, meliputi procedure, different representations, features, reversibility connection, dan meaning as connection.

Proses koneksi matematis merupakan aktivitas mental dalam mengoneksikan ide-ide matematis. Proses koneksi matematis membutuhkan pemikiran yang kompleks seperti menduga, menjustifikasi dan menafsirkan masalah (Aguirre dkk., 2013). Menurut (Ramatlapana \& Berger, 2018) proses koneksi melibatkan pembuatan argumen, justifikasi dan dugaan saat memproses informasi. Akuisisi pengetahuan matematika dapat diakses atau dianalisis melalui eksplorasi bagaimana peserta didik mengatur struktur kognitif matematika. (Adu-Gyamfi dkk, 2017) menemukan lima proses kompleks yang dialami siswa ketika membangun koneksi melalui masalah matematika antara lain, yakni: menduga, menafsirkan, menghitung, membandingkan hasil temuan sebelumnya, dan menggeneralisasikan hasil.

Masalah merupakan suatu istilah yang familiar dalam matematika. Posamentier \& Krulik (2009) mendeskripsikan masalah adalah situasi yang dihadapi siswa ketika membutuhkan solusi, namun cara untuk menemukan solusinya tidak langsung diketahui. Sementara itu, Brookhart (2010) menyatakan bahwa masalah merupakan proses mencari solusi yang tidak dapat dipecahkan secara hafalan. Selanjutnya masalah matematika merupakan teka-teki yang tidak ada ketentuan jelas tentang cara penyelesaiannya dan berhubungan dengan matematika (Small, 2017). Dari ketiga pernyataan tersebut, peneliti menafsirkan bahwa masalah matematika merupakan masalah non rutin yang solusinya membutuhkan proses bernalar dan tidak dapat dipecahkan secara langsung.

Masalah-masalah yang sering digunakan dalam pembelajaran matematika akan berdampak pada pola pikir siswa. Ciriciri masalah matematika antara lain: tidak rutin, menantang, dan masih berada dalam lingkup pikiran siswa. Salah satu masalah matematika yang dapat diberikan kepada siswa adalah masalah geometri. Masalah yang berkaitan dengan geometri dapat memberikan kesempatan kepada siswa untuk membuat koneksi secara luas. Hal ini dikarenakan ide-ide geometri terorganisir dalam struktur koneksi (Ramatlapana \& Berger, 2018). Materi tentang geometri akan dibahas dalam penelitian ini, khususnya masalah segiempat. Segiempat didefinisikan sebagai suatu poligon yang memiliki tepat empat sisi (Alexander \& Koeberlein, 2015).

\section{METODE}

Pendekatan yang digunakan dalam penelitian ini adalah pendekatan kualitatif berjenis deskriptif-eksploratif. Penelitian ini dilaksanakan di SMP Negeri 5 Malang pada semester genap tahun ajaran 2018/2019. Subjek dalam penelitian ini adalah siswa kelas VIII yang telah mempelajari materi segiempat. Pemilihan subjek dalam penelitian ini didasarkan pada siswa yang mengindikasi koneksi matematis pada lembar jawaban. Subjek penelitian juga dipilih berdasarkan pada kemampuan siswa dalam berkomunikasi secara verbal. Tujuannya yaitu, agar subjek terpilih dapat mengemukakan pendapatknya secara mendalam tentang proses berpikirnya dalam menyelesaikan masalah yang diberikan.

Instrumen yang digunakan dalam penelitian ini berupa tes dan protokol wawancara sehingga data yang diperoleh pada penelitian ini berupa data kualitatif. Data kualitatif tersebut berupa deskripsi dari hasil eksplorasi terhadap pengerjaan siswa baik secara tertulis maupun wawancara dalam menyelesaikan masalah segiempat. Berikut merupakan instrumen tes yang diberikan kepada siswa. 


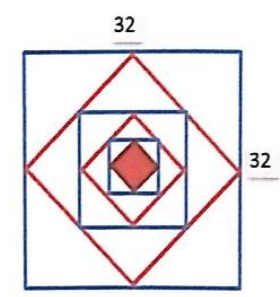

Gambar di atas merupakan bangun persegi yang di dalamnya juga terdiri dari bangun persegi. Titik sudut dari setiap persegi yang berada di dalam merupakan titik tengah dari panjang sisi persegi yang berada di luarnya. Jika diketahui panjang sisi persegi paling luar adalah $32 \mathrm{~cm}$, maka berapakah luas bangun persegi yang diarsir? Tentukan rumus dari luas dua persegi yang berurutan/berdekatan!

\section{Gambar 1. Masalah Segiempat}

\section{HASIL}

Berdasarkan pekerjaan siswa pada lembar jawaban maupun wawancara yang dilakukan pada saat penelitian, diperoleh satu siswa yang memenuhi kriteria subjek penelitian. Subjek penelitian adalah siswa dengan inisial SW. Jawaban dari SW mengindikasi proses koneksi matematis, meliputi menduga, menafsirkan, membandingkan, menghitung, dan menggeneralisasikan.

Koneksi yang terjadi ketika SW menyelesaikan masalah dimulai dengan mengoneksikan ukuran persegi ke-1 (yang diketahui) dengan teorema pythagoras, sehingga diperoleh ukuran persegi ke-2. Kemudian SW mengoneksikan ukuran persegi ke-1 dan ke-2 dengan rumus luas persegi panjang, sehingga diperoleh luas persegi ke-1 dan ke-2. Setelah itu, SW menyederhanakan panjang sisi persegi yang telah ditemukan untuk mencari luas persegi selanjutnya. Selanjutnya, SW membandingkan hasil yang diperoleh (yaitu membandingkan luas persegi yang berdekatan) dan menduga adanya pola pada gambar yang diketahui. Sehingga SW menduga bahwa persegi yang berdekatan mempunyai perbandingan yang sama besar. Dengan demikian, SW dapat dapat menentukan rumus luas dua persegi yang berurutan/berdekatan dan dapat menentukan luas persegi yang diarsir. Berikut merupakan jawaban secara tertulis dari SW ketika menyelesaikan masalah.

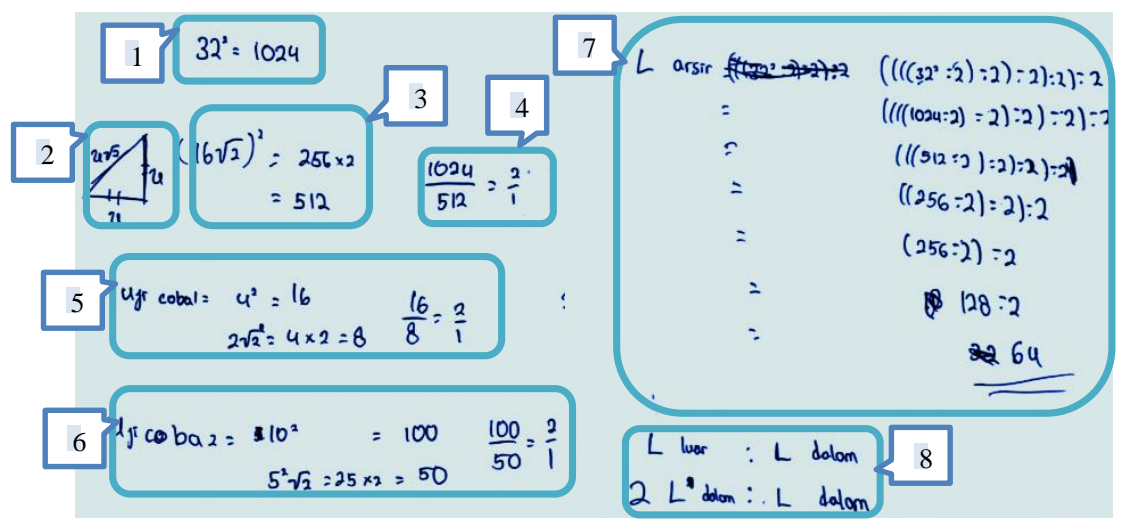

\section{Gambar 2. Hasil Pengerjaan SW dalam Menyelesaikan Masalah}

Deskripsi proses koneksi matematis SW secara tertulis berdasarkan gambar 1 menunjukkan bahwa SW menyelesaikan masalah dimulai dengan membuat perhitungan terhadap luas persegi ke-1 (seperti tanda 1) dengan cara mengkuadratkan panjang sisi yang diketahui seperti yang telah dituliskan $32^{2}=1024$. Pada kasus ini, SW melakukan penafsiran terhadap luas persegi melalui rumus persegi yaitu $\mathrm{L}=\mathrm{s}^{2}$. Langkah yang ini mengindikasi koneksi antara ukuran persegi ke-1 dengan rumus luas persegi panjang, sehingga diperoleh luas persegi ke-1. Selanjutnya, tanda 2 SW membuat gambar segitiga sama kaki yang juga merupakan segitiga siku-siku yang sisi-sisinya disimbolkan dengan $\mathrm{x}$ (simbol panjang sisi segitiga yang mempunyai ukuran sama) dan $\mathrm{x} \sqrt{2}$ (simbol panjang sisi miring). SW menentukan panjang sisi miring dari segitiga tersebut dapat melibatkan aturan teorema pythagoras. Sisi miring tersebut merupakan sisi persegi ke-2. Langkah ini mengindikasi koneksi antara ukuran persegi ke-1 dengan teorema pythagoras, sehingga diperoleh ukuran persegi ke-2.

Pada tanda 3, SW melakukan perhitungan terhadap luas persegi ke-2 dengan cara mengkuadratkan panjang sisi yang diketahui seperti pada tanda 1 dan diperoleh luasnya adalah 512. Langkah ini mengindikasi koneksi antara ukuran persegi ke-2 dengan rumus luas persegi panjang, sehingga diperoleh luas persegi ke-2. Kemudian tanda 4, SW melakukan perbandingan 
hasil dari luas persegi yang berurutan yaitu membagi luas persegi ke-1 dengan luas persegi ke-2. SW melakukan perhitungan dengan membagi luas persegi ke-1 dan persegi ke-2, dan diperoleh perbandingan 2: 1. Langkah ini mengindikasi koneksi antara luas persegi yang berurutan/berdekatan konsep perbandingan, sehingga diperoleh perbandingan luas persegi yang berurutan/berdekatan.

SW membuat dua contoh kasus, yaitu ujicoba 1 (pada tanda 5) dan ujicoba 2 (pada tanda 6). Pada ujicoba 1, panjang sisi persegi ke-3 yaitu 4 (disebut ukuran persegi ke-3) dan panjang sisi ke-4 yaitu $2 \sqrt{2}$ (disebut ukuran persegi ke-4), sedangkan pada ujicoba 2, panjang sisi persegi ke-5 yaitu 10 (disebut ukuran persegi ke-5) dan panjang sisi ke-6 yaitu $5 \sqrt{2}$ (disebut ukuran persegi ke-6). Kemudian SW, melakukan perhitungan dengan cara yang sama seperti tanda 3 dan 4 sehingga diperoleh perbandingan $2: 1$. SW membuat contoh kasus (ujicoba 1 dan 2) yang berbeda dengan masalah yang diberikan, yakni ukuran sisi-sisi yang digunakan pada ujicoba 1 dan 2 tidak sama dengan informasi yang diberikan. Pada langkah ini, SW telah melakukan perbandingan dua luas seperti langkah-langkah yang dilakukan sebelumnya sehingga dapat melihat adanya kesamaan pola perbandingan dari luas persegi yang berurutan adalah $2: 1$. Langkah ini juga mengindikasi koneksi antara luas persegi yang berurutan/berdekatan konsep perbandingan, sehingga diperoleh perbandingan luas persegi yang berurutan/berdekatan.

Selanjutnya tanda 7, SW membuat persamaan tehadap luas yang diarsir dengan menuliskan $\mathrm{L}_{\text {arsir }}=$ $\left(\left(\left(\left(32^{2}: 2\right): 2\right): 2\right): 2\right): 2$. Artinya, SW membuat dugaan terhadap luas persegi yang diarsir. Pada langkah ini, SW melakukan penafsiran terhadap luas persegi yang diarsir (persegi yang berada pada urutan kelima setelah persegi ke-1) adalah pembagian antara luas persegi terluar dengan dua sebanyak lima kali. SW membagi dua karena melihat kesamaan pola perbandingan dari luas persegi yang berurutan adalah $2: 1$. Kemudian, SW melakukan perhitungan dan diperoleh luas yang diarsir adalah 64 Langkah ini mengindikasi koneksi antara perbandingan luas persegi yang berurutan/berdekatan dengan konsep pembagian, sehingga diperoleh luas persegi yang diarsir.

Kemudian, SW melakukan generalisasi terhadap rumus dua persegi yang berurutan/berdekatan melalui kesamaan pola dari perbandingan luas yang ditemukan. SW membuat dugaan terhadap luas dari dua persegi yang berurutan/ berdekatan adalah $\mathrm{L}_{\text {luar: }} \mathrm{L}_{\text {dalam }}$ atau $2 \mathrm{~L}_{\text {dalam }}$ : $\mathrm{L}_{\text {dalam }}$. SW melakukan penafsiran luas persegi luar adalah dua kali luas persegi dalam. $\mathrm{SW}$ membuat permisalan bahwa $\mathrm{L}_{\text {dalam }}$ adalah luas persegi yang ada di dalam, sedangkan $\mathrm{L}_{\text {luar }}$ adalah luas persegi yang di luarnya persegi dalam tersebut. Langkah ini juga mengindikasi koneksi antara luas persegi yang berurutan/berdekatan dengan konsep perbandingan, sehingga diperoleh rumus luas persegi yang berurutan/berdekatan. Berikut merupakan kutipan wawancara yang dilakukan oleh subjek penelitian (S) dan peneliti (P) ditinjau dari tahapan pemecahan masalah:

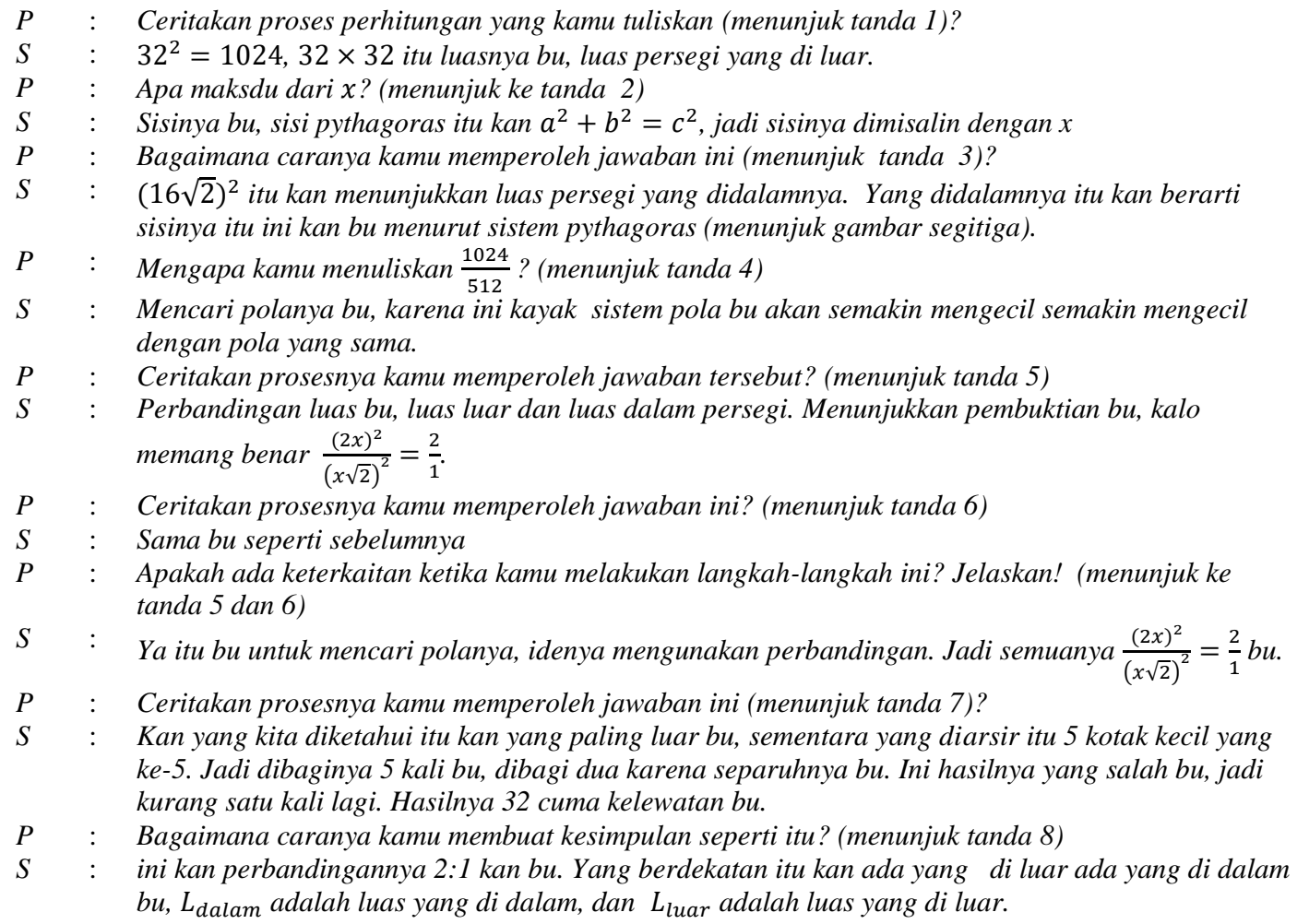


Berdasarkan kutipan wawancara SW dalam menyelesaikan masalah dapat diketahui bahwa SW mengoneksikan ukuran persegi ke-1 dengan teorema pythagoras sehingga diperoleh ukuran persegi ke-2. Seperti pernyataan S2 ketika diwawancarai "sisi pythagoras itu kan $a^{2}+b^{2}=c^{2}$, jadi sisinya dimisalin dengan $x$ ". SW membuat permisalan panjang sisi yang sama pada segitiga sama kaki dengan $x$, sehingga jika panjang sisi miringnya dihitung dengan melibatkan teorema pythagoras diperoleh $x \sqrt{2}$. Kemudian, SW menghitung panjang sisi persegi ke-2 dan diperoleh $16 \sqrt{2}$. Selanjutnya mengoneksikan ukuran persegi ke-1 dan ke-2 dengan rumus luas persegi panjang, sehingga diperoleh luas persegi ke-1 dan ke-2. SW menentukan luas persegi ke-1 dan ke-2 dengan menafsirkan rumus luas persegi melalui rumus $L=s^{2}$. Setelah itu, SW menghitung luas persegi ke-1 dan ke-2 dengan mensubstitusikan ukuran sisi yang diketahui terhadap rumus $L=s^{2}$ dan diperoleh luas persegi ke-1 adalah $1024 \mathrm{~cm}^{2}$ dan luas persegi ke-2 adalah $512 \mathrm{~cm}^{2}$.

Langkah berikutnya, SW mengoneksikan luas persegi yang berurutan/berdekatan konsep perbandingan, sehingga diperoleh perbandingan luas persegi yang berurutan/berdekatan. SW membandingkan luas persegi ke-1 dan ke-2 untuk menentukan luas persegi yang berurutan/berdekatan. Sehingga diperoleh perbandingan $2: 1$. Pada langkah ini SW menduga adanya kesamaan untuk setiap perbandingan luas persegi yang berurutan/berdekatan. Kemudian, SW membuat ujicoba 1 dan ujicoba 2 untuk membuktikan apakah rumus $\frac{(2 x)^{2}}{(x \sqrt{2})^{2}}$ berlaku jika digunakan untuk menghitung luas persegi lainnya. Pada ujicoba 1, panjang sisi persegi adalah 4 (disebut ukuran persegi ke-3) dan panjang sisi ke-4 yaitu $2 \sqrt{2}$ (disebut ukuran persegi ke-4). Sedangkan pada ujicoba 2, panjang sisi persegi ke-5 yaitu 10 (disebut ukuran persegi ke-5) dan panjang sisi ke-6 yaitu $5 \sqrt{2}$ (disebut ukuran persegi ke-6). Kemudian SW, menghitung luas masing-masing persegi pada ujicoba 1 dan 2 , lalu membandingkan luas persegi ke-1 dan ke-2 diperoleh perbandingan $2: 1$. Pada kasus ini SW mengujicobakan panjang sisi yang lebih sederhana dan tidak sama dengan soal. SW memberikan contoh kasus yang perbandingan ukuran sisi-sisinya sama.

Selanjutnya SW mengoneksikan perbandingan luas persegi yang berurutan/ berdekatan dengan konsep pembagian, sehingga diperoleh luas persegi yang diarsir. SW menafsirkan luas persegi yang diarsir dengan melihat perbandingan yang diperoleh. Karena persegi yang diarsir merupakan persegi yang berada pada urutan kelima setelah persegi ke-1, maka SW menyatakan bahwa luas persegi yang diarsir didapatkan dari pembagian antara luas persegi terluar dengan dua sebanyak lima kali. Pembagi 2 mengacu pada kesamaan pola perbandingan dari luas persegi yang berurutan adalah $2: 1$. Perhitungan luas yang diarsir sebenarnya adalah $32 \mathrm{~cm}^{2}$, tetapi SW ceroboh dalam menghitung. Hal ini ditunjukkan ketika SW menyatakan "Hasilnya 32 cuma kelewatan bu".

Setelah itu, SW mengoneksikan luas persegi yang berurutan/berdekatan dengan konsep perbandingan, sehingga diperoleh rumus luas persegi yang berurutan/berdekatan. SW menggeneralisasikan rumus dua persegi yang berurutan/ berdekatan dengan melihat kesamaan pola perbandingan luas yang didapatkan pada langkah sebelumnya (yaitu 2:1). Sehingga SW menduga luas dua persegi yang berurutan/berdekatan adalah $L_{\text {luar }}: L_{\text {dalam }}$ atau $2 L_{\text {dalam }}: L_{\text {dalam }}$. SW menafsirkan luas persegi luar adalah dua kali luas persegi dalam. SW menyatakan bahwa $L_{\text {dalam }}$ adalah luas persegi yang ada di dalam, sedangkan $L_{\text {luar }}$ adalah luas persegi yang di luarnya persegi dalam tersebut. Proses koneksi matematis subjek penelitian ketika menyelesaikan masalah dapat digambarkan seperti diagram alur sebagaimana ditunjukkan pada gambar 3.

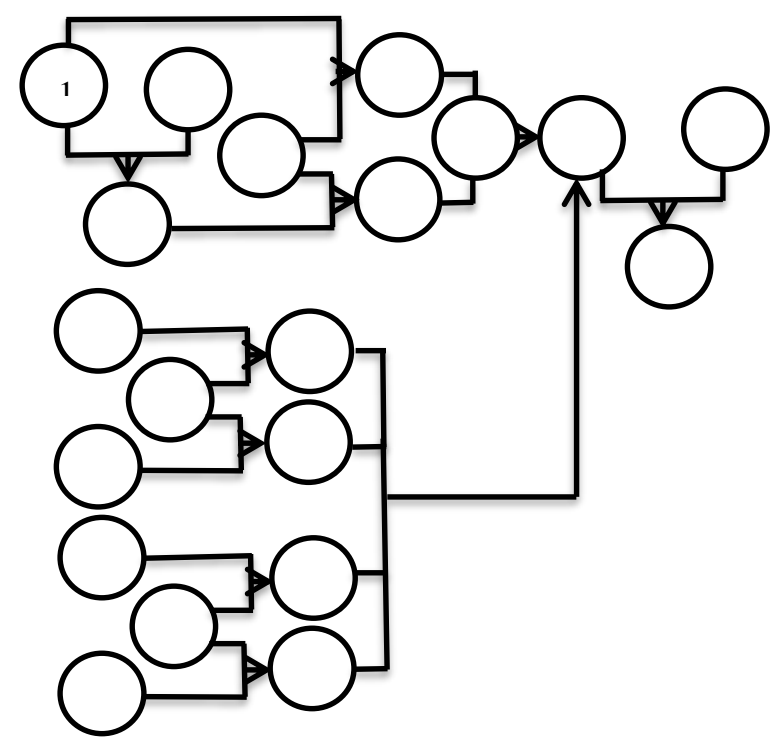

Gambar 3. Alur Proses Koneksi Matematis SW 
Tabel 1. Deskripsi Proses Koneksi SW

\begin{tabular}{|c|c|}
\hline No & Deskripsi \\
\hline 1 & Mengidentifikasi ukuran persegi ke-1 \\
\hline 2 & Mengaitkan dengan teorema Pythagoras \\
\hline 3 & Mengoneksikan ukuran persegi ke-1 dengan teorema pythagoras, sehingga diperoleh ukuran persegi ke-2 \\
\hline 4 & Mengaitkan rumus luas persegi panjang \\
\hline 5 & Mengoneksikan ukuran persegi ke-1 dengan rumus luas persegi panjang, sehingga diperoleh luas persegi ke-1 \\
\hline 6 & Mengoneksikan ukuran persegi ke-2 dengan rumus luas persegi panjang, sehingga diperoleh luas persegi ke-2 \\
\hline 7 & Mengaitkan dengan konsep perbandingan \\
\hline 8 & $\begin{array}{l}\text { Mengoneksikan luas persegi yang berurutan/berdekatan dengan konsep perbandingan, sehingga diperoleh perbandingan luas persegi } \\
\text { yang berurutan/berdekatan }\end{array}$ \\
\hline 9 & Mengaitkan dengan konsep pembagian \\
\hline 10 & $\begin{array}{l}\text { Mengoneksikan perbandingan luas persegi yang berurutan/ berdekatan dengan konsep pembagian, sehingga diperoleh luas persegi yang } \\
\text { diarsir }\end{array}$ \\
\hline 11 & Menyederhanakan ukuran persegi ke-1 (diperoleh ukuran persegi ke-3) \\
\hline 12 & Menyederhanakan ukuran persegi ke-2 (diperoleh ukuran persegi ke-4) \\
\hline 13 & Mengaitkan dengan rumus luas persegi panjang \\
\hline 14 & Mengoneksikan ukuran persegi ke-3 dengan rumus luas persegi panjang, sehingga diperoleh luas persegi ke-3 \\
\hline 15 & Mengoneksikan ukuran persegi ke-4 dengan rumus luas persegi panjang, sehingga diperoleh luas persegi ke-4 \\
\hline 16 & Menyederhanakan ukuran persegi ke-1 (diperoleh ukuran persegi ke-5) \\
\hline 17 & Menyederhanakan ukuran persegi ke-2 (diperoleh ukuran persegi ke-6) \\
\hline 18 & Mengaitkan dengan rumus luas persegi panjang \\
\hline 19 & Mengoneksikan ukuran persegi ke-5 dengan rumus luas persegi panjang, sehingga diperoleh luas persegi ke-5 \\
\hline 20 & Mengoneksikan ukuran persegi ke-6 dengan rumus luas persegi panjang, sehingga diperoleh luas persegi ke-6 \\
\hline
\end{tabular}

\section{PEMBAHASAN}

Koneksi yang dibuat oleh SW dalam menyelesaikan masalah termasuk dalam kategori koneksi berkembang. Koneksi berkembang, terjadi ketika siswa mampu bernalar secara logis dalam mengembangkan koneksi baru melalui masalah yang sama dengan konteks masalah yang diberikan. Artinya, siswa mampu mengembangkan pengetahuan baru dari sebelumnya yang memungkinkan terjadi koneksi yang lebih kompleks dan memungkinkan banyaknya jalur asimilasi. Seperti pendapat Connolly \& Spiller (2017) bahwa kompleksitas yang lebih besar dalam organisasi pengetahuan, memungkinkan banyak jalur untuk asimilasi pengetahuan baru dengan pengetahuan sebelumnya. Situasi seperti ini, menunjukkan adanya perkembangan pemikiran siswa dalam bermatematika yang nantinya akan menghasilkan suatu nilai kelogisan dari pemikiran tersebut. Seperti pernyataan Niu dkk (2017) bahwa pengembangan berpikir matematis siswa dapat menumbuhkan pemahaman mereka tentang pemikiran logis. Pemikiran siswa dianggap logis ketika siswa tersebut mampu menghasilkan jawaban secara masuk akal sesuai dengan aturan matematika baik secara tertulis maupun menjelaskan secara lisan. Hal ini selaras dengan penemuan Dandotkar dkk (2016) bahwa koneksi logis bisa dilihat dari hasil pengerjaan siswa secara tertulis dan wawancara, wawancara dilakukan untuk meyakinkan pembaca melalui klaim.

Koneksi berkembang terjadi ketika SW menduga perbandingan antara luas dua persegi yang berurutan/berdekatan adalah sama. Pada langkah ini, SW membuat dua contoh kasus yang sama seperti masalah yang diberikan tetapi menggunakan ukuran yang lebih sederhana, yakni ujicoba 1 dan 2. Dalam hal ini, SW mengoneksikan luas dua persegi yang berurutan/berdekatan dengan konsep perbandingan, untuk memperoleh perbandingan luas dua persegi. Ketika melakukan ujicoba tersebut, SW menyederhanakan ukuran sisi-sisi persegi yang diketahui. Penyederhanaan ukuran persegi tersebut, didasari oleh penemuan sebelumnya tentang perbandingan luas persegi ke-1 dan persegi ke-2, dan melihat adanya pola pada gambar yang diketahui. Dengan demikian, dapat dikatakan bahwa SW mengembangkan pengetahuan yang koheren. Berkembangnya pemikiran siswa dalam matematika dapat dilihat dari pengembangan pengetahuan koheren yang diciptakan oleh mereka (Huang \& Li, 2012). Didukung oleh penyataan Suh \& Seshaiyer (2015) bahwa struktur koheren yang dibangun oleh siswa, dapat dilihat melalui pola pikiran siswa dalam pengembangan ide-ide matematika dengan mengetahui konsep apa yang mendasarinya.

Sebelum menentukan perbandingan luas dua persegi yang berurutan/ berdekatan, awalnya SW menentukan panjang sisi persegi yang belum diketahui. Dalam hal ini, SW membuat koneksi secara visual antara gambar yang berbeda (yaitu mengoneksikan bangun persegi dengan segitiga siku-siku, ketika ingin menentukan panjang sisi persegi yang berada di dalamnya). Seperti pernyataan Ramatlapana \& Berger (2018) bahwa koneksi visual dibuat ketika siswa mengatur hubungan antara figural dan representasi lainnya. Contoh koneksi visual ini adalah koneksi (a) antara verbal dan gambar, (b) antara simbol dan gambar, (c) antara gambar yang berbeda dan (d) antara definisi dan gambar. Dengan demikian, SW dapat mengembangkan suatu koneksi secara logis didasarkan oleh pemahamannya terhadap koneksi yang saling terkait (interkoneksi). Seperti pernyataan Ramatlapana \& Berger (2018) bahwa implikasi koneksi yang dibuat siswa menunjukkan hubungan logis antara prinsip-prinsip matematika dan konfigurasi yang diidentifikasi. 
Contoh kasus yang sama seperti yang telah dibuat oleh SW (ketika melakukan ujicoba 1 dan 2) menunjukkan bahwa SW mampu untuk melakukan manipulasi ukuran persegi yang diketahui. Artinya, SW telah melakukan eksplorasi terhadap masalah yang diberikan, dan mengidentifikasi apakah sifat-sifat dari masalah yang diberikan juga bisa ditransfer pada situasi yang lain. Oleh karena itu, SW dapat mengetahui sifat-sifat atau aspek-aspek dan hubungan dari kedua masalah tersebut. Hal ini sesuai dengan pernyataaan Huang \& Li (2012), melalui kegiatan eksplolasi dari situasi tertentu, siswa dapat mengembangkan pengetahuan baru lebih lanjut melalui kegiatan manipulatif. Didukung oleh Fuchs dkk (2014), bahwa penekanan pertama dalam melakukan suatu koneksi adalah pengetahuan yang saling terkait untuk mengeksplorasi hubungan terbalik.

Ujicoba 1 dan ujicoba 2 merupakan salah satu metode yang digunakan oleh SW untuk mencari cara yang lebih mudah dalam membuat generalisasi rumus luas dua persegi yang berurutan/berdekatan. Seperti pendapat Eli, dkk (2013) bahwa pembangunan suatu koneksi dapat memudahkan siswa dalam menyelesaikan masalah. Dalam hal ini, SW mengidentifikasi masalah-masalah yang terkait melalui interkoneksi yang ada. Kemudian, SW membuat pengembangan koneksi baru secara logis tanpa memakai rumus formal, dan disesuaikan dengan masalah yang diberikan. Hal ini selaras dengan pernyataan Lemonidis dkk (2018) bahwa siswa akan tahu apa yang dilakukan dan mengapa siswa tersebut melakukannya tanpa mengandalkan aturan rumus-rumus yang harus dihafalkan apabila siswa tersebut telah memahami interkoneksi yang telah dibuat oleh mereka sendiri. Dengan demikian, SW dapat mengembangkan koneksi baru yang sesuai dengan konteks masalah yang diberikan. Seperti pernyataan Zengin (2019) bahwa siswa dapat membuat koneksi antara ide-ide baru dan yang relevan dalam menyelesaikan suatu masalah.

\section{SIMPULAN}

Penelitian tentang proses koneksi matematis siswa kelas VIII masalah segiempat menghasilkan kesimpulan bahwa proses koneksi matematis yang dilakukan, meliputi menduga, menafsirkan, menghitung, membandingkan, dan menggeneralisasikan. Koneksi matematis yang dibuat oleh siswa dikategorikan sebagai koneksi berkembang. Siswa dikatakan menghasilkan koneksi berkembang, ketika siswa mampu bernalar secara logis dalam mengembangkan koneksi baru melalui masalah yang sama dengan konteks masalah yang diberikan.

Berdasarkan hasil penelitian tentang proses koneksi matematis siswa kelas VIII masalah segiempat akan dideskripsikan dua saran. Pertama, bagi guru, sebaiknya memberikan soal yang lebih bervariasi, yaitu memuat lebih banyak materi-materi karena akan memunculkan koneksi siswa secara luas. Kedua, bagi peneliti lain yang ingin melakukan penelitian sejenis, sebaiknya mengembangkan penelitian ini dengan cara mengategorikan subjek penelitian berdasarkan kemampuan tinggi, sedang, dan rendah. Hal ini bertujuan agar peneliti lebih mengetahui secara mendalam koneksi matematis yang dibuat oleh siswa ditinjau dari kemampuan matematisnya.

\section{DAFTAR RUJUKAN}

Adu-Gyamfi, K., Bossé, M. J., \& Chandler, K. (2017). Student Connections between Algebraic and Graphical Polynomial Representations in the Context of a Polynomial Relation. International Journal of Science and Mathematics Education, 15(5), 915-938. https://doi.org/10.1007/s10763-016-9730-1

Aguirre, J. M., Turner, E. E., Bartell, T. G., Kalinec-Craig, C., Foote, M. Q., Roth McDuffie, A., \& Drake, C. (2013). Making Connections in Practice: How Prospective Elementary Teachers Connect to Children's Mathematical Thinking and Community Funds of Knowledge in Mathematics Instruction. Journal of Teacher Education, 64(2), 178-192. https://doi.org/10.1177/0022487112466900

Alexander, D. C., \& Koeberlein, G. M. (2015). Elementary Geometry for College Students (Sixth Edition). Australia: Stamford, CT: Cengage Learning.

Arjudin, Sutawidjaja, A., Irawan, B. E., \& Sa'dijah, C. (2016). Characterization of Mathematical Connection Errors in Derivative Problem Solving. Journal of Research \& Method in Education (IOSR-JRME), 6(5), 7-12. https://doi.org/10.9790/7388-0605050712

Connolly, H., \& Spiller, D. (2017). Developing Knowledge Connections to Promote an Integrated Learning Experience for Students in a First Year Management Course. Journal of Management Education, 41(6), 873-906. https://doi.org/10.1177/1052562916686632

Dandotkar, S., Magliano, J. P., \& Britt, M. A. (2016). Effect Logical Relatedness and Semantic Overlap on Argument Evaluation. Discourse Processes, 53(7), 581-602. https://doi.org/10.1080/0163853X.2015.1087295

Downton, A., \& Sullivan, P. (2017). Posing Complex Problems Requiring Multiplicative Thinking Prompts Students to Use Sophisticated Strategies and Build Mathematical Connections. Educational Studies in Mathematics, 95(3), $303-328$. https://doi.org/10.1007/s10649-017-9751-x

Eli, J. A., Mohr-Schroeder, M. J., \& Lee, C. W. (2013). Mathematical Connections and Their Relationship to Mathematics Knowledge for Teaching Geometry: Mathematical Connections and MKT Geometry. School Science and Mathematics, 113(3), 120-134. https://doi.org/10.1111/ssm.12009 
Fuchs, L. S., Powell, S. R., Cirino, P. T., Schumacher, R. F., Marrin, S., Hamlett, C. L., ... Changas, P. C. (2014). Does Calculation or Word-Problem Instruction Provide a Stronger Route to Prealgebraic Knowledge? Journal of Educational Psychology, 106(4), 990-1006. https://doi.org/10.1037/a0036793

García-García, J., \& Dolores-Flores, C. (2018). Intra-Mathematical Connections Made by High School Students in Performing Calculus Tasks. International Journal of Mathematical Education in Science and Technology, 49(2), $227-252$. https://doi.org/10.1080/0020739X.2017.1355994

Huang, R., \& Li, Y. (2012). What Matters Most: A Comparison of Expert and Novice Teachers' Noticing of Mathematics Classroom Events: What Matters Most. School Science and Mathematics, 112(7), 420-432. https://doi.org/10.1111/j.1949-8594.2012.00161.x

Islami, M. D., Sunardi, S., \& Slamin, S. (2018). The Mathematical Connections Process of Junior High School Students with High and Low Logical Mathematical Intelligence in Solving Geometry Problems. International Journal of Advanced Engineering Research and Science, 5(4), 10-18. https://doi.org/10.22161/ijaers.5.4.3

Kuneni, E., Mardiyana, \& Pramudya, I. (2017). The Development of a Valid Discovery-Based Learning Module to Improve Students' Mathematical Connection. 1-6. https://doi.org/10.1063/1.4995164

Lemonidis, C., Tsakiridou, H., \& Meliopoulou, I. (2018). In-Service Teachers' Content and Pedagogical Content Knowledge in Mental Calculations with Rational Numbers. International Journal of Science and Mathematics Education, 16(6), 1127-1145. https://doi.org/10.1007/s10763-017-9822-6

Lockwood, E. (2011). Student Connections among Counting Problems: An Exploration Using Actor-Oriented Transfer. Educational Studies in Mathematics, 78(3), 307-322. https://doi.org/10.1007/s10649-011-9320-7

Niu, W., Zhou, Z., \& Zhou, X. (2017). Understanding the Chinese Approach to Creative Teaching in Mathematics Classrooms. ZDM, 49(7), 1023-1031. https://doi.org/10.1007/s11858-017-0887-Z

Ozgen, K. (2016). A Theoretical Study on the Mathematical Connection. Dalam W. Wu, M. T. Hebebci, \& T. Ozturk (Ed.), International Conference on Research in Education and Science (hlm. 220-230). Bodrum/Turkey: ISRES Publishing.

Ramatlapana, K., \& Berger, M. (2018). Prospective Mathematics Teachers' Perceptual and Discursive Apprehensions when Making Geometric Connections. African Journal of Research in Mathematics, Science and Technology Education, 22(2), 162-173. https://doi.org/10.1080/18117295.2018.1466495

Small, M. (2017). Teaching Mathematical Thinking: Tasks and Questions to Strengthen Practices and Processes. New York, NY: Teachers College Press.

Suh, J., \& Seshaiyer, P. (2015). Examining Teachers' Understanding of the Mathematical Learning Progression Through Vertical Articulation During Lesson Study. Journal of Mathematics Teacher Education, 18(3), 207-229. https://doi.org/10.1007/s10857-014-9282-7

Zengin, Y. (2019). Development of Mathematical Connection Skills in a Dynamic Learning Environment. Education and Information Technologies, 24(3), 2175-2194. https://doi.org/10.1007/s10639-019-09870-x 